\title{
Physical-Mechanical Characterization of Moriche Natural Fibre (Mauritia flexuosa) and Composite with Bio-epoxy Resin
}

\author{
William Javier Mora Espinosa* - Bladimir Azdrubal Ramón Valencia - Gonzalo G. Moreno Contreras \\ University of Pamplona, Colombia
}

The characterization of natural fibres is currently used in the field of science and engineering of materials with the purpose of developing new bio-composites friendly to the environment. The goal of this research is to manufacture and characterize a bio-composite reinforced with Moriche palm fibre (Mauritia flexuosa) and to determine the thermal, mechanical and morphological properties of the fibre. Subsequently, the tensile and flexion properties of the composite was evaluated, as well as its morphology. The thermogravimetric analysis demonstrated that the fibre has hydrophilic characteristics and good stability at temperatures close to $200{ }^{\circ} \mathrm{C}$. In the tensile test under static axial forces, its modulus of elasticity, stress and maximum deformation was determined. Its morphology, composed of the small lumen and wide cell wall with size variations, was examined with scanning electron microscopy (SEM). In the same way, the maximum tensile stress of the composite leads to the conclusion that it is viable to use this material for applications in non-structural elements, which are below $25 \mathrm{MPa}$. The results of maximum flexural strength (253.7 MPa) allow more extensive applications in doubly supported or overhanging parts subjected to concentrated or distributed loads. The microstructure obtained with SEM showed a poor adhesion between the matrix and the reinforcement.

Keywords: natural fibres, bio-composite, reinforcement, characterization

Highlights

- The natural fibre was characterized thermally, mechanically, and morphologically.

- A uniform $45^{\circ}$ artisan fabric was used as reinforcement in the bio-composite.

- $\quad$ The tensile and flexural properties in the bio-composite were determined, and the adhesion was evaluated by means of a SEM test.

- $\quad$ The flexural properties obtained allow the bio-composite to be used in simply supported components that support different types of loads.

\section{INTRODUCTION}

Recently, increasing attention has been given towards the development of green (or eco-friendly) products in the field of composites, motivating a wide range of research on the use of matrices and reinforcements of types of organic materials in its production [1]. The utilization of natural fibres as substitutes for traditional synthetic fibres (glass and carbon), used as reinforcement in biologically based and synthetically based matrices, for properties such as: mechanical strength, high specific modulus, density, low weight, thermal stability, low cost, lower energy requirement, less wear on processing, wide availability, excellent biodegradability, and resistance to deforestation [2].

The most commonly used natural-type reinforcements are lignocellulosic fibres, constituted of crystalline microstructures formed by cellulose and other spirals connected by amorphous lignin and hemicellulose [3]. The mechanical strength of the fibre is directly related to the angle of these cellulose fibrils; a lower angle ensures a better mechanical response of the fibre [4]. Its mechanical, thermal, and structural properties allow multiple uses in industry, mainly for manufacturing parts, in sectors such as automotive and packaging [5], displacing conventional materials in some applications, especially compounds made with synthetic fibres of glass, carbon and other manmade fibres [6], particularly in applications where low maintenance and weather resistance are required [7]. Composites are widely used in various industrial applications because of their properties and ease of tailoring to meet specific requirements [8]. The automotive sector has focused on applications mainly for interiors and semi-structural uses, for which stem fibres have dominated, both in thermoplastic and thermostable matrices [9].

Colombia has more than 26,000 species of plants [10]; many of them produce fibres, which are only used at the artisanal level [11], to supply basic needs or to manufacture implements such as bags, hats, rugs, baskets, and sacks [12] and [13]. This research focuses on the Moriche palm fibre (MPF) that comes from the young leaves of the plant located between $30 \mathrm{~m}$ and $40 \mathrm{~m}$, according to the height of the palm [14]. By processes such as extraction, defibration, cooking, and drying, the leaves are transformed into fibres for use by craftsmen in the manufacturing of various fabrics [12], mainly in the Tucano and Nukak Maku ethnic groups' residents in the Colombian Amazon [15]. 
The potential as a reinforcement in bio-composite materials was evaluated by finding its thermal stability using thermogravimetric (TG) curves. The mechanical behaviour was obtained with a uniaxial tension test adjusted to the ASTM D3822/D3822M-14 standard [16], determining the resistance of the cellulose micro-fibrils coupled within an amorphous matrix of lignin and hemi-cellulose that constitute the fibre [17]. Finally, the microstructure was observed through a scanning electron microscope (SEM), allowing determination of the influence of its geometry on the tensile strength, where the lumen and the cell wall thickness are the determining factors of the mechanical properties of the fibre [18]. When making a comparison with other natural fibres investigated by various authors, the viability of this fibre was validated in the development of new low-cost materials and friendly to the environment.

Once the fibre has been characterized and validated, it is used as a reinforcement to make a biocomposite through the vacuum assisted resin transfer moulding process (VARTM) [19], with an epoxy resin matrix obtained from agro-industrial waste [20]. The material obtained is mechanically characterized by tensile and bending tests using ASTM D3039/ D3039M-14 [21] and ASTM D790-15 [22] standards, respectively. The microstructure observed via the SEM test enabled an evaluation of the adhesion between the fibre and the resin. When the mechanical properties were obtained, and the adhesion verified, the bio-composite was compared with other materials reinforced with natural fibres to identify possible application fields.

\section{METHODS AND MATERIALS}

The methods used to determine the properties of fibre and bio-composite are based on standardized procedures for ASTM, thermogravimetric analysis (TGA), and SEM tests.

The manufacture of the compound using vacuumassisted resin transfer moulding (VARTM) method was adapted from an industrial process.

\subsection{Reinforcement of Moriche Palm Fibre}

The MPF can reach a height of 40 meters in the Amazon region, taking a diameter of $30 \mathrm{~cm}$ to 60 $\mathrm{cm}$ and ends in a crown of 15 to 20 palmate leaves arranged in a spiral, approximately 2.5 meters long and $4.5 \mathrm{~m}$ wide [14]. The fibres are extracted from their young leaves (bud) to make various products such as bags, roofs of houses, ropes, hammocks, mats, baskets, fishing nets, ceremonial garments, among others [13], the palm and a textile fibre fabric are shown in Fig. 1.

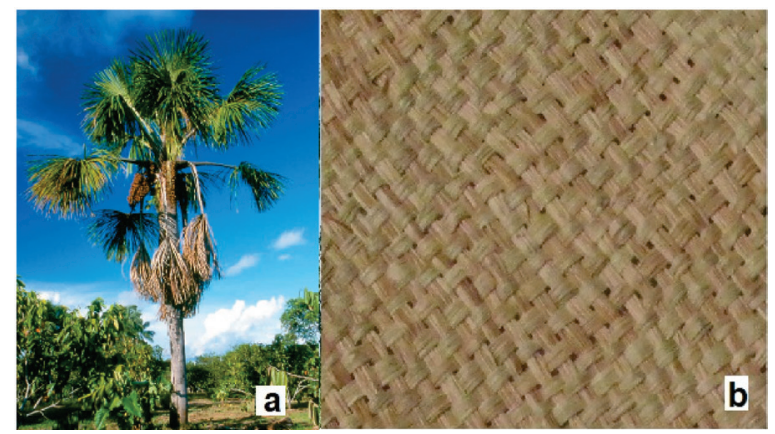

Fig. 1. a) Moriche palm, and b) textile fibre fabric, (Reproduced from [15])

\subsection{Bio-epoxy Resin Matrix}

The matrix to manufacture the bio-composite is a modified liquid epoxy resin (Super Sap CLR epoxy) and a hardener of two speeds: Super Sap INF (fast and slow). Unlike traditional resins composed primarily of petroleum-based materials, Super Sap formulations contain renewable biofuel materials obtained as coproducts or from industrial process waste, such as wood pulp and biofuel production [20].

\subsection{Fibre Thermogravimetric Analysis (TGA)}

The thermal stability of the fibres was evaluated in the laboratory using an SDT Q600 TA Instruments machine, at a heating rate of $10{ }^{\circ} \mathrm{C} / \mathrm{min}$, until reaching $600{ }^{\circ} \mathrm{C}$ in a nitrogen controlled inert atmosphere. The samples were crushed until obtaining fine size with weights between $5 \mathrm{mg}$ and $10 \mathrm{mg}$ and placed in alumina capsules stable at high temperatures.

The graphs of thermal decomposition: percentage of weight vs temperature (TG) and its first derivative percentage of weight per min vs temperature difference thermo-gravimetry (DTG) for lignocellulosic fibres, generally show a first mass loss, attributed by several authors to the vaporization of the water absorbed into the fibre; the second mass loss process represents the degradation initiation, with thermal stability in the fibres up to about $200{ }^{\circ} \mathrm{C}$ [23].

\subsection{Natural Fibres Tensile Test}

The mechanical characterization was carried out by tensile testing with the ASTM standard D3822/ D3822M-14, (Standard test method for tensile properties of single textile fibres) [16], measured with 
a Shimazu UH 600 KNI universal testing machine. The conditions of the test were room temperature (20 $\left.{ }^{\circ} \mathrm{C}\right)$, deformation speed $(1 \mathrm{~mm} / \mathrm{min})$, and calibrated length $(20 \mathrm{~mm})$.

\subsection{Morphology of Natural Fibres (SEM Test)}

The microstructure was observed using a scanning electron microscope (JEOL model JSM 6490-LV) with $3.0 \mathrm{~nm}$ resolutions, and using a voltage of $30 \mathrm{KV}$ with high vacuum isolation, covering the crosssection of the sample with a thin layer of gold to allow conductivity.

\subsection{Manufacture of Bio-composite}

The braided fibre reinforcement was hand-made by the Tukano and Guayabero Indians of the Panuré reservation in San José del Guaviare, Colombia [24]. To make the fabric they initially extract and dry the fibres, then select the homogeneous threads to interlock them manually until obtaining a uniform, balanced bidirectional fabric at $45^{\circ}$. The resin matrix bio Super Sap CLR epoxy is adequate for the VARTM method in mixed in a ratio of 100: 33 (resin: hardener) by weight, until obtaining a viscosity of $490 \mathrm{cPs}$ to guarantee good fluidity [20].

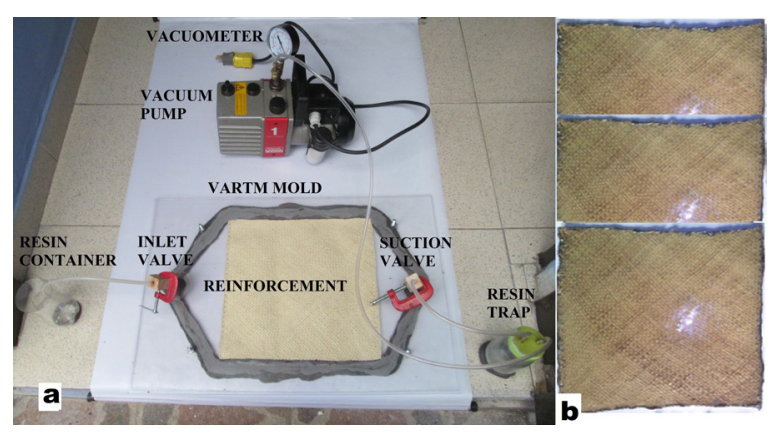

Fig. 2. a) Assembly for VARTM method, and b) Moriche/bio-epoxy laminate

The Moriche textile fibre fabric was used without physical-chemical treatments, cutting sections of $20 \mathrm{~cm} \times 30 \mathrm{~cm}$ with a grammage of $8.833 \mathrm{~g} / \mathrm{cm}^{2}$. Laminates of the material reinforced with woven fibres were made, using the assembly shown in Fig. 2a. After impregnating all the fibre, the vacuum is maintained by closing the valves (inlet and outlet) for 24 hours for curing. Finally, the laminate is obtained (Fig. 2b).

\subsection{Bio-composite Characterization}

The specimens were obtained by cutting the biocomposite laminates with dimensions according to ASTM D3039/D3039M-14 [21], for traction in polymer matrix composite materials. The test speed is $1 \mathrm{~mm} / \mathrm{min}$ at room temperature and $52 \%$ relative humidity. Five specimens with a calibrated length of $100 \mathrm{~mm}$ were tested, using a system of flat jaws in the Shimazu UH 600 KNI universal machine.

The bending tests for Moriche/epoxy specimens were adjusted to ASTM D790-15 [22], for nonreinforced, reinforced plastics and insulating materials. The test conditions were at a speed of 2 $\mathrm{mm} / \mathrm{min}$ and room temperature. Five specimens were tested in the Shimazu UH 600 KNI universal machine, using an accessory for three-point bending, with 100 $\mathrm{mm}$ between supports.

\section{RESULTS AND DISCUSSION}

\subsection{Tensile Test of the Fibre}

The characteristic behaviour of Moriche fibre when evaluated by ASTM D3822 / 3822M-14 standard [16], is shown in the strength-strain diagram of Fig. 3.

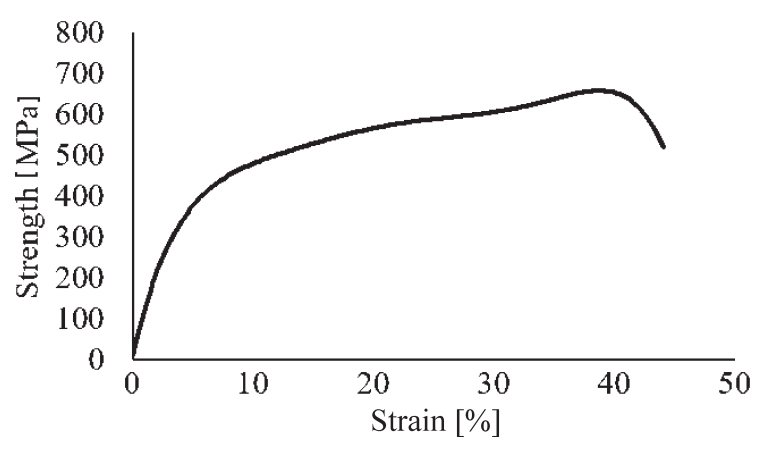

Fig. 3. Moriche Fibre strength-strain diagram

Fig. 3 shows an elastic (linear) zone associated to the deformation of the cell wall (cellulose microfibrils) and a plastic zone (non-linear) due to the delamination of cellulose and the orientation of the amorphous phase (lignin, pectin and hemicellulose) [25]. The average values and standard deviation for the modulus of elasticity, the maximum tensile strength and the maximum deformation are presented in Table 1.

The maximum strength in Table 1 shows a low standard deviation value compared with previous investigations for fibres such as flax $(1000 \pm 500$ MPa) [26], okra (233.8 $\pm 126.4 \mathrm{MPa})$ [27] and ramie $(586.5 \pm 351.5 \mathrm{MPa})[28]$. 
Table 1. Mechanical properties of MPF

\begin{tabular}{ccccc}
\hline $\begin{array}{c}\text { Cross } \\
\text { section } \\
{[\mathrm{mm} \times \mathrm{mm}]}\end{array}$ & $\begin{array}{c}\text { Gage } \\
\text { length } \\
{[\mathrm{mm}]}\end{array}$ & $\begin{array}{c}\text { Tensile } \\
\text { strength } \\
{[\mathrm{MPa}]}\end{array}$ & $\begin{array}{c}\text { Young's } \\
\text { modulus } \\
{[\mathrm{GPa}]}\end{array}$ & $\begin{array}{c}\text { Breaking } \\
\text { strain } \\
{[\%]}\end{array}$ \\
\hline $0.1 \times 2$ & 20 & $585.03 \pm 178.4$ & $9.53 \pm 2.8$ & $40.57 \pm 27.6$ \\
\hline
\end{tabular}

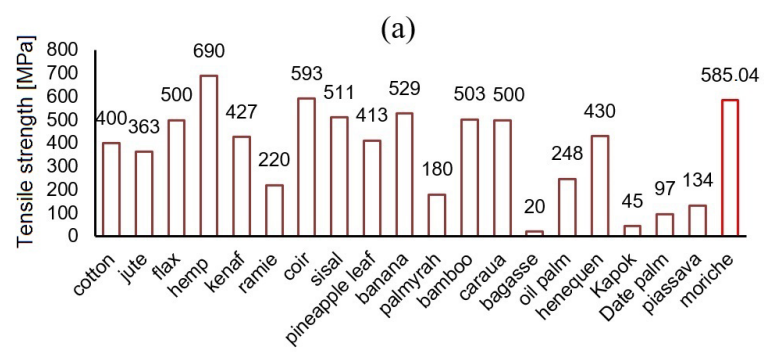

(b)

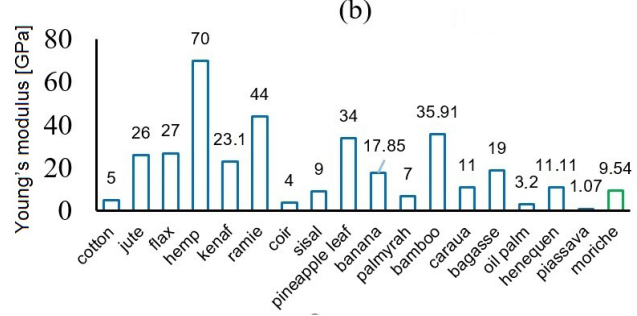

(c)

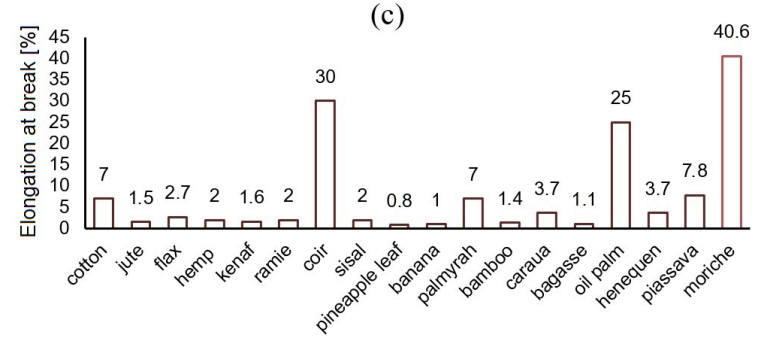

Fig. 4. a) Tensile strength, b) Young's modulus, and c) elongation at break in various natural fibres vs Moriche fibre, adapted from

[34]

The values of maximum tensile strength allow the selection of MPF as a possible alternative to be used as reinforcement in bio-composite materials by overcoming fibres (Fig. 4a), such as jute [29], kenaf [30], flax [31], sisal [32] and cotton [33], used in the development of these materials. Although the module obtained shows representative variations with respect to fibres such as flax, hemp, jute, ramie, and kenaf; there are similarities between the MPF and the sisal fibre [34], as shown in Fig. 4b. The maximum elongation value of MPF was $40.58 \%$ with elastoplastic behaviour [35], but higher than most natural fibres, where the coconut fiber [34] obtained a similar value, as shown in Fig. 4c.

\subsection{Fibre Thermal Stability}

The behaviour of the TG graph of the MPF is shown in Fig. 5.

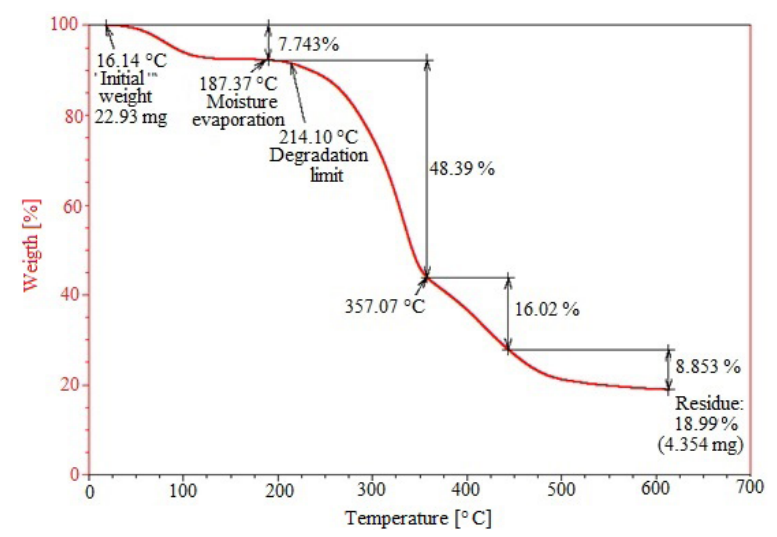

Fig. 5. TG fibre Moriche curve

The hydrophilicity or moisture retention in reinforcement with lignocelluloses fibres is one great drawback for polymer composites [36]. The moisture generates a weak interfacial bond; causing the reduction in the mechanical properties of the composite [37].

For MPF, a percentage of humidity of $7.74 \%$ is obtained in a range of $\left(18{ }^{\circ} \mathrm{C}\right.$ to $\left.187^{\circ} \mathrm{C}\right)$, similar to that of other fibres such as althaea $\left(25^{\circ} \mathrm{C}\right.$ to $\left.135^{\circ} \mathrm{C}\right)$ [28], areca $\left(30{ }^{\circ} \mathrm{C}\right.$ to $\left.100{ }^{\circ} \mathrm{C}\right)$ [38], cissus $\left(25^{\circ} \mathrm{C}\right.$ to $\left.175^{\circ} \mathrm{C}\right)$ [39], proporis $\left(25^{\circ} \mathrm{C}\right.$ to $\left.110^{\circ} \mathrm{C}\right)$ [4] and okra $\left(30{ }^{\circ} \mathrm{C}\right.$ to $\left.110{ }^{\circ} \mathrm{C}\right)$ [27]. This percentage generates a negative effect on adhesion, so it is recommended to perform a preliminary physical-chemical treatment before adding it to the matrix.

Maintaining the temperature below the limit of fibre degradation ensures that it maintains its mechanical properties during the manufacturing processes of the bio-composite by extrusion or injection moulding in thermoplastics [18]. The limit of the beginning of the degradation of MPF is given at $214{ }^{\circ} \mathrm{C}$, with values close to other fibres such as artichoke $\left(230{ }^{\circ} \mathrm{C}\right)$, bamboo $\left(214{ }^{\circ} \mathrm{C}\right)$, bagasse $(222$ $\left.{ }^{\circ} \mathrm{C}\right)$ [[40], okra $\left(220^{\circ} \mathrm{C}\right)$, hemp $\left(250^{\circ} \mathrm{C}\right)$, curauá $(230$ $\left.{ }^{\circ} \mathrm{C}\right)$, kenaf $\left(219^{\circ} \mathrm{C}\right)$ and jute $\left(205^{\circ} \mathrm{C}\right)[27]$.

\subsection{Moriche Fibre Morphology}

The micrographs of MPF show a uniform distribution of cells along the cut (see Fig. 6), the size of the lumen is large from $8 \mu \mathrm{m}$ to $10 \mu \mathrm{m}$, as well as its cell wall, which in some areas equals the lumen, whose dimensions oscillate between $5 \mu \mathrm{m}$ and $10 \mu \mathrm{m}$. The 
fibre tends to be more massive at one end but, in general, its structure is symmetrical.

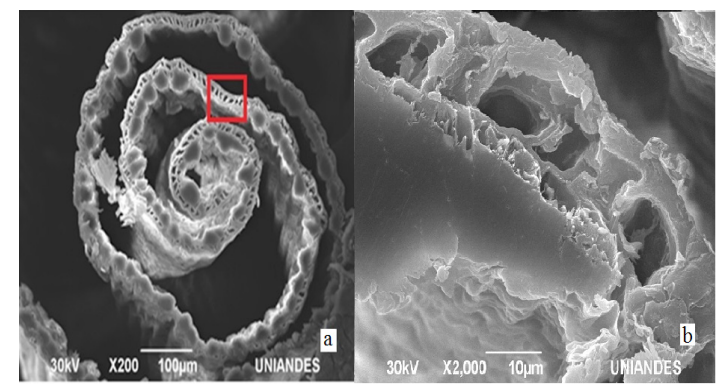

Fig. 6. Microstructure of MPF at a) $\times 200$ and b) $\times 2000$

The images obtained have similar morphological characteristics between MPF and other fibres, such as jute, sisal, curaua, coconut, artichoke (Cynara cardunculus L.) [40], piassava [41], okra (Abelmoschus esculentus) [27], marshmallow (Althaea officinalis L) [28], shell of betel nut (Areca catechu) [38], cabecinegro fibre (manicaria saccifera) [42], and sugar cane fibre [43].

As the cell wall is responsible for supporting the force, especially the microfibrils of cellulose, the micrographs of MPF validate the results obtained in the mechanical behaviour, because the axial force is evenly distributed in a larger support area by having robust and symmetrical cell walls.

\subsection{Bio-composite Tensile Test}

The behaviour of the bio-composite tensile material is shown in Fig. 7.

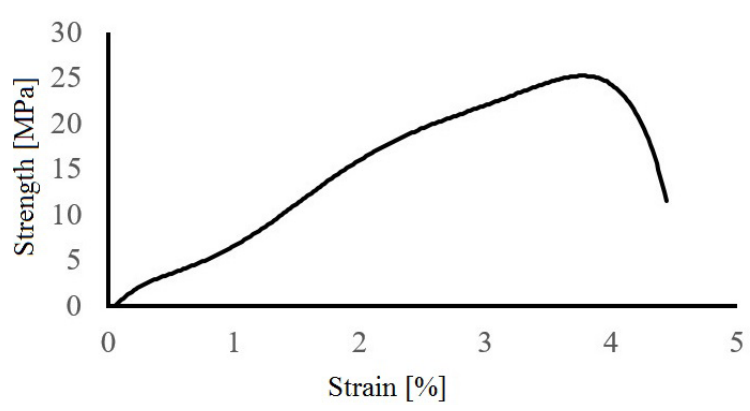

Fig. 7. Tensile behaviour of MPF-bio-epoxy composite

The results of Young's modulus averages, maximum tensile strength and strain are shown in Table 2.

The results of the mechanical properties show a fragile behaviour due to the low percentages in the strain. In contrast, the differences are more significant in the resistance and the module. The behaviour in the stiffness, measured with the elastic modulus was diminished by almost a third for the MPF. The possible cause of this variation is mainly due to the low compatibility of the reinforcements with bio-epoxy resin, attributed to excess moisture in the fibre, affecting the adhesion. The low value of strength is a consequence of the delamination of the reinforcement when subjected to axial forces due to tissue orientation.

Table 2. Properties of the MPF bio-composite

\begin{tabular}{lc}
\hline Properties & MPF/bio-epoxy \\
\hline Tensile strength [MPa] & $25.02 \pm 0.48$ \\
\hline Young's modulus [GPa] & $9.17 \pm 7.00$ \\
\hline Breaking strain [\%] & $3.77 \pm 0.65$ \\
\hline
\end{tabular}

\subsection{Bio-composite Flexural Test}

In Fig. 8, an elastoplastic behaviour is observed, in the first elastic zone, the flexural modulus has similar values (slope); however, the strengths have more dispersed behaviours in the plastic zone.

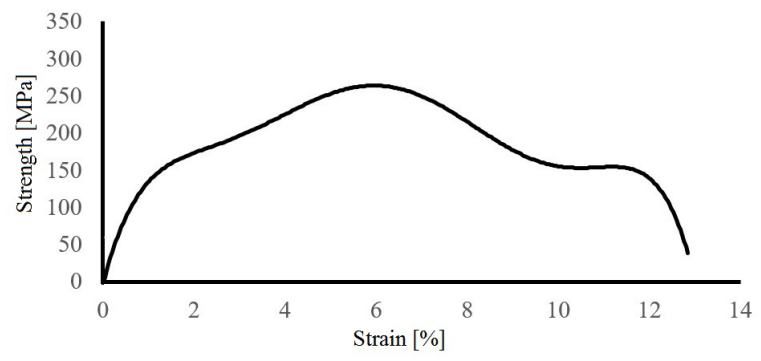

Fig. 8. Flexural behaviour of MPF-bio-epoxy composite

The strength in the plastic area presents a small variation that is due to the alignment of the microfibrils after the delamination of the amorphous and crystalline components in the direction of the load. This behaviour occurs below the neutral axis where the specimen is located in traction. The strength in the upper part depends only on the resin because the reinforcement does not act in compression.

The average values of strength to flexion, modulus and strain were obtained by descriptive statistics; the results are shown in Table 3 .

Table 3. Average values of strength, strain and flexural modulus for the MPF bio-composite

\begin{tabular}{lc}
\hline Properties & MPF/bio-epoxy \\
\hline Flexural strength [MPa] & $253.75 \pm 43.31$ \\
\hline Flexural modulus [GPa] & $10.9 \pm 2.0$ \\
\hline Breaking strain [\%] & $28.45 \pm 3.75$ \\
\hline
\end{tabular}


The mechanical properties of tensile/flexural strength and Young's modulus were compared with other polymer matrix bio-composites evaluated by different authors. Table 4 shows the results obtained.

Table 4. Mechanical properties of various bio-composites developed vs MPF-bio-epoxy

\begin{tabular}{|c|c|c|c|c|}
\hline Composite & $\begin{array}{c}\text { Tensile } \\
\text { strength } \\
{[\mathrm{MPa}]} \\
\end{array}$ & $\begin{array}{c}\text { Flexural } \\
\text { strength } \\
{[\mathrm{MPa}]}\end{array}$ & $\begin{array}{c}\text { Young's } \\
\text { modulus } \\
{[\mathrm{GPa}]}\end{array}$ & Ref. \\
\hline sisal/polyester & 40 & 77 & 2.13 & \multirow{9}{*}{ [44] } \\
\hline jute/polyester & 66.01 & 93.8 & 4.42 & \\
\hline coco/polyester & 20.4 & 41.54 & 1.2 to 2 & \\
\hline banana/cotton/polyester & 30.96 & 61.24 & 2.03 & \\
\hline Pineapple leaf/polyester & 43.38 & 85.81 & & \\
\hline jute/epoxy & 104 & 150 & 15.04 & \\
\hline bamboo/PBS & 32 & 40.5 & 0.9 & \\
\hline Oil palm/ HDPE & 12.5 & 248.1 & 0.39 & \\
\hline Straw/PP & 33 & 1200 & 1.18 & \\
\hline Abaca/PLA & 74 & - & 8.34 & \multirow{4}{*}{ [1] } \\
\hline Abaca/PP & 42 & - & 4.9 & \\
\hline Flax/PP & 42 & 67 & 3.2 & \\
\hline Hemp/PP & 42 & 70 & 3 & \\
\hline Moriche/Bio-epoxy & 25.02 & 253.74 & 9.17 & \\
\hline
\end{tabular}

The composite developed with MPF and bioepoxy resin obtained intermediate values between the coconut/polyester composite and the banana/ cotton/polyester tested under traction. In contrast, the comparison of flexural strength presents higher values than those reported in other investigations that are only surpassed by the straw/PP composite.

These results define a limited application only in components that do not need to be of a structural type or that are subjected to high loads and whose tensile strengths do not exceed $25 \mathrm{MPa}$. Regarding the values of flexural strength, the results allow wider applications in parts subjected to concentrated or distributed loads, either double-supported or cantilevered.

\subsection{Microstructure of the Bio-composite}

In Fig. 9, the three zones of the bio-composite are observed, the reinforcement (MPF), the matrix (bioepoxy resin) and the interface between the two materials. It is worth noting again the poor adhesion between the micro-constituents, showing an interface with a separation between materials close to $20 \mu \mathrm{m}$. The absence of interaction between the natural fibre and the bio-epoxy resin proves the low mechanical properties of this system, causing the composite to be delaminated under the effect of the axial force applied in the tensile test.

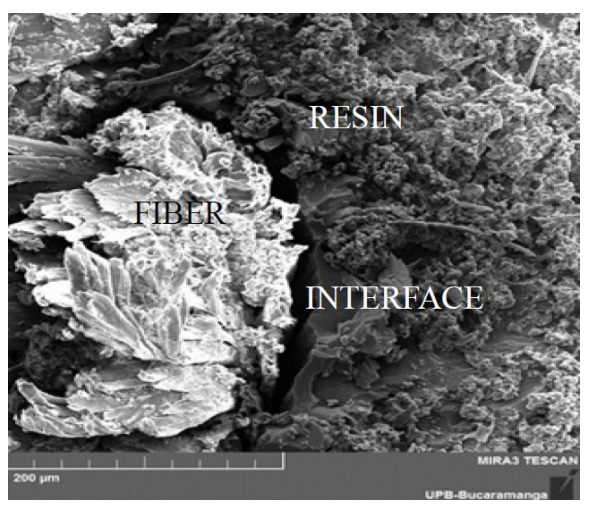

Fig. 9. Micrography of MPF/bio-epoxy composite

As explained in the TGA test, the natural fibre is hydrophilic, that is, they tend to retain a significant percentage of moisture, and as a consequence, the interfacial junctions with the hydrophobic matrix are affected, decreasing the mechanical properties of the bio-composite.

\section{CONCLUSIONS}

Mechanical tests showed that the MPF is a good alternative for reinforcement in bio-composite polymer matrix materials, due to its excellent tensile strength properties with respect to various fibres investigated by other authors.

The thermal analysis enabled determining both the moisture content of the fibre and the limit of the beginning of degradation of the fibre, defining with these results the need for a previous drying process and the type of matrix that can be used. With these parameters, the loss of mechanical properties due to excess temperature in the manufacturing process is avoided. The effect of moisture on the mechanical properties was evidenced in the results obtained for the bio-composite.

The scanning electron microscopy enabled understanding the direct relationship that exists between the results of the mechanical tests and the microstructure of the fibre, allowing to observe a robust cell wall, where the axial load to which the fibre is subjected is distributed in a uniform way. In the case of the bio-composite, it was possible to demonstrate a very poor adhesion between the fibre and the matrix.

The low tensile strength value is also due to the orientation of the fibres in the fabric used, so it is advisable to manufacture a uniform balanced fabric at 
$90^{\circ}$ so that the reinforcement is oriented properly in the direction of the loads.

Once the mechanical, thermal, and morphological properties of the fibre and Moriche-bio-epoxy composite have been compared with other compounds reinforced with natural fibres, it is demonstrated that the MPF has a very high potential in the field of environmentally friendly materials, making a pretreatment to improve adhesion.

\section{ACKNOWLEDGEMENTS}

This research study was supported by the University of Pamplona - Colombia. The authors declare that there is no conflict of interest regarding the publication of this paper.

\section{REFERENCES}

[1] Anshu, A., Singh, Afrin, S., Karim, Z. (2017). Green Composites: Versatile Material for Future. M. Jawaid et al. (eds.) Green Biocomposites, Green Energy and Technology, p. 30-44, Springer, Cham, Dol:10.1007/978-3-319-49382-4_2.

[2] Saba, N., Jawaid, M., Alothman, O.Y., Paridah, M.T. (2016). A review on dynamic mechanical properties of natural fibre reinforced polymer composites. Construction and Building Materials, vol. 106, p. 149-159, D0l:10.1016/j. conbuildmat.2015.12.075.

[3] Pereira, P.H.F., Rosa, M. de F., Cioffi, M.O.H., Benini, K.C.C. de C., Milanese, A.C., Voorwald, H.J.C., Mulinari, D.R. (2015). Vegetal fibers in polymeric composites: a review. Polímeros, vol. 25, no. 1, p. 9-22, Dol:10.1590/0104-1428.1722.

[4] Fiore, V., Scalici, T., Valenza, A. (2014). Characterization of a new natural fiber from Arundo donax $L$. as potential reinforcement of polymer composites. Carbohydrate Polymers, vol. 106, p. 77-83, D0l:10.1016/j.carbpol.2014.02.016.

[5] Kommula, V.P., Kanchireddy, O.R., Shukla, M., Marwala, T. (2014). Effect of acid treatment on the chemical, structural, thermal and tensile properties of napier grass fibre strands. International Conference on Advances in Marine, Industrial and Mechanical Engineering, Johannesburg, p. 45-51.

[6] Ramesh, M., Palanikumar, K., Hemachandra Reddy, K. (2017). Plant fibre based bio-composites: Sustainable and renewable green. Renewable and Sustainable Energy Reviews, vol. 79, p. 558-584, D0l:10.1016/j.rser.2017.05.094.

[7] AL-Oqla, F.M., Sapuan, S.M. (2014). Natural fiber reinforced polymer composites in industrial applications: feasibility of date palm fibers for sustainable automotive industry. Journal of Cleaner Production, vol. 66, p.347-354, D0l:10.1016/j. jclepro.2013.10.050.

[8] Murat, B.I.S., Fromme, P., Endrizzei, M., Olivo, A. (2018). Characterization of Impact Damage in Composite Plates. Strojniški vestnik - Journal of Mechanical Engineering, vol. 64, no. 11, p. 672-680, Dol:10.5545/sv-jme.2017.5186.

[9] Barari, B., Omrani, E., Moghadam, A.D., Menezes, P.L., Pillai, K.M., Rohatgi, P.K. (2016). Mechanical, physical and tribological characterization of nano-cellulose fibers reinforced bio-epoxy composites: An attempt to fabricate and scale the 'Green' composite. Carbohydrate Polymer, vol. 147, p. 282293, D0l:10.1016/j.carbpol.2016.03.097.

[10] Moreno, L.A., Andrade, G.l., y Ruíz-Contreras, L.F. (eds.). (2016). Biodiversity 2016. Status and Trends of Continental Biodiversity in Colombia. Research Institute of Biological Resources Alexander von Humboldt. Bogotá, D.C., Colombia. $106 \mathrm{p}$.

[11] García, N., Galeano, G., Mesa, L., Casta-o, N., Balslev, H., Bernal, R. (2015). Management of the palm Astrocaryum chambira Burret (Arecaceae) in northwest Amazon. Acta Botanica Brasilica, vol. 29, no. 1, p. 45-57, D0l:10.1590/0102$33062014 a b b 3415$.

[12] Artesanias de Colombia, (2014). from http://www. artesaniasdecolombia.com.co.

[13] Mesa Castellanos, L., Toro Buitrago, A., Isaza Aranguren, C. (2017). Management of Mauritia flexuosa I.f. for the production of crafts in the Colombian highlands. Forest Colombia, vol. 20. p. 85-101, D0l:10.14483/udistrital.jour. colomb.for.2017.1.a07. (in Spanish)

[14] Virapongse, A., Endress, B.A., Gilmore, M.P., Horn, C., Romulo, C. (2017). Ecology, livelihoods, and management of the Mauritia flexuosa palm in South America. Global Ecology and Conservation, vol. 10, p. 70-92, D0l:10.1016/j. gecco.2016.12.005.

[15] SINCHI Institute and Corpoamazonia (2007). Ecology, use and sustainable management of nine species of plants from the department of Amazonas, generators of timber and non-timber products. Ministry of environment, housing and territorial development, Bogotá (Colombia). (in Spanish)

[16] ASTM D3822/D3822M:2014. Standard Test Method for Tensile Properties of Single Textile Fibers. American Society for Testing and Materials. USA.

[17] Jose Chirayil, C., Mathew, L., Thomas, S. (2014). Review of recent research in nano cellulose preparation from different lignocellulosic fibers. Reviews on Advanced Materials Science, vol. 37, no.1-2, p. 20-28.

[18] Pickering, K.L., Aruan Efendy, M.G., Le T.M. (2016). A review of recent developments in natural fibre composites and their mechanical performance. Composites Part A: Applied Science and Manufacturing, vol. 83, p. 98-112, D0l:10.1016/j. compositesa.2015.08.038.

[19] Schuster, J., Govignon, Q., Bickerton, S. (2014). Processability of biobased thermoset resins and flax fibres reinforcements using vacuum assisted resin transfer moulding. Open Journal of Composite Materials, vol. 4, no. 1, p. 1-11, D0l:10.4236/ ojcm.2014.41001.

[20] Entropy resins, Super Sap INF System Entropy Resins Inc. (2016). from https://entropyresins.com/product/super-sapclr-clear-epoxy-resin/, accessed on 2016-03-12.

[21] ASTM D3039/D3039M:2014. Standard Test Method for Tensile Properties of Polymer Matrix Composite Materials. American Society for Testing and Materials. USA.

[22] ASTM D790:2015. Standard Test Method for Flexural Properties of Unreinforced and Reinforced Plastics and Electrical Insulating Materials. American Society for Testing and Materials. USA. 
[23] Maache, M., Bezazi, A., Amroune, S., Scarpa, F., Dufresne, A. (2017). Characterization of a novel natural cellulosic fiber from Juncus effusus L. Carbohydrate Polymers, vol. 171, p. 163172, DOl:10.1016/j.carbpol.2017.04.096.

[24] Municipality of San Jose del Guaviare (2008). Comprehensive Plan for Indigenous Life - Panuré Resguardo, Department of Guaviare, San José del Guaviare. (in Spanish)

[25] Fiore, V., Scalici, T., Valenza, A. (2014). Characterization of a new natural fiber from Arundo donax $L$. as potential reinforcement of polymer composites. Carbohydrate Polymers, vol. 106, p. 77-83, D0l:10.1016/j.carbpol.2014.02.016.

[26] Hughes, M. (2012). Defects in natural fibres: their origin, characteristics and implications for natural fibre-reinforced composites. Journal of Materials Science, vol. 47, no. 2, p. 599-609, DOl:10.1007/s10853-011-6025-3.

[27] De Rosa, I.M., Kenny, J.M. Maniruzzaman, M., Moniruzzaman, M., Monti, M., Puglia, D., Santulli, C., Sarasini, F. (2011). Effect of chemical treatments on the mechanical and thermal behaviour of okra (Abelmoschus esculentus) fibres. Composites Science and Technology, vol. 71, no. 2, p. 246254, D0l:10.1016/j.compscitech.2010.11.023.

[28] Sarikanat, M., Seki, Y., Sever, K., Durmuskahya, C. (2014). Determination of properties of Althaea officinalis $L$. (Marshmallow) fibres as a potential plant fibre in polymeric composite materials. Composites Part B, Engineering, vol. 57, p. 180-186, D0l:10.1016/J.compositesb.2013.09.041.

[29] Sanjay, M.R., Madhu, P., Jawaid, M., Senthamaraikannan, P., Senthil, S., Pradeep, S. (2018). Characterization and properties of natural fiber polymer composites: A comprehensive review. Journal of Cleaner Production, vol. 172, p. 566-581, D0I:10.1016/j.jclepro.2017.10.101.

[30] Faruk, O., Bledzki, A.K., Fink, H.-P., Sain, M. (2014). Progress report on natural fiber reinforced composites. Macromolecular Materials and Engineering, vol. 299, no. 1, p. 9-26, DOl:10.1002/mame.201300008.

[31] Moothoo, J., Allaoui, S., Ouagne, P., Soulat, D. (2014). A study of the tensile behaviour of flax tows and their potential for composite processing. Materials \& Design, vol. 55, p. 764772, D0l:10.1016/J.matdes.2013.10.048.

[32] Senthilkumar, K., Saba, N., Rajini, N., Chandrasekar, M., Jawaid, M., Siengchin, S., Alotman, O.Y. (2018). Mechanical properties evaluation of sisal fibre reinforced polymer composites: A review. Construction and Building Materials, vol. 174, p. 713-729, D0I:10.1016/j.conbuildmat.2018.04.143.

[33] Layth, M., Ansari, M.N.M., Pua, G., Jawaid, M., Islam, M.S. (2015). A review on natural fiber reinforced polymer composite and its applications. International Journal of Polymer Science, vol. 2015, p. 1-15, D0I:10.1155/2015/243947.

[34] Müssig, J. (ed.) (2010). Industrial Applications of Natural Fibres. Structure, Properties and Technical Applications, University of Applied Sciences, John Wiley \& Sons, Bremen, DOI:10.1002/9780470660324.
[35] Fuentes, C.A., Willekens, P., Petit, J., Thouminot, C, Müssig, J., Trindade, L.M., Van Vuure, A.W. (2017). Effect of the middle lamella biochemical composition on the non-linear behaviour of technical fibres of hemp under tensile loading using strain mapping. Composites Part A: Applied Science and Manufacturing, vol. 101, p. 529-542, D0l:10.1016/j. compositesa.2017.07.017.

[36] Stanciu, M.D., Savin, A., Nastac, S. (2018). Mechanical and surface properties of lignocellulosic fibres reinforced composites. Strojniški vestnik - Journal of Mechanical Engineering, vol. 64, no. 11, p. 698-705, D0l:10.5545/svjme.2018.5352.

[37] Ridzuan, M.J.M., Abdul Majid, M.S., Afendi, M., Aqmariah Kanafiah, S.N., Zahri, J.M., Gibson, A.G. (2018). Characterisation of natural cellulosic fibre from Pennisetum purpureum stem as potential reinforcement of polymer composites. Materials \& Design, vol. 89, p. 839-847, D0I:10.1016/j.matdes.2015.10.052.

[38] Yusriah, L., Sapuan, S.M., Zainudin, E.S., Mariatti, M. (2014). Characterization of physical, mechanical, thermal and morphological properties of agro-waste betel nut (Areca catechu) husk fibre. Journal of Cleaner Production, vol. 72, p. 174-180, DOI:10.1016/j.jclepro.2014.02.025.

[39] Indran, S., Edwin Raj, R., Sreenivasan, V.S. (2014). Characterization of new natural cellulosic fiber from Cissus quadrangularis root. Carbohydrate Polymers, vol. 110, p. 423429, D0I:10.1016/j.carbpol.2014.04.051.

[40] Fiore, V., Valenza, A., Di Bella, G. (2011). Artichoke (Cynara cardunculus L.) fibres as potential reinforcement of composite structures. Composites Science and Technology, vol. 71, no. 8, p. 1138-1144, D0l:10.1016/j.compscitech.2011.04.003.

[41] Alves Fidelis, M.E., Castro Pereira, T.V., Martins Gomes, O.F., Silva, F.A., Toledo Folho, R.D. (2013). The effect of fiber morphology on the tensile strength of natural fibers. Journal of Materials Research and Technology, vol. 2, no. 2, p. 149-157, DOI:10.1016/j.jmrt.2013.02.003.

[42] Porras, A., Maranon, A., Ashcroft, I.A. (2016). Thermomechanical characterization of Manicaria Saccifera natural fabric reinforced poly-lactic acid composite lamina. Composites Part A: Applied Science and Manufacturing, vol. 81, p. 105-110, D0I:10.1016/j.compositesa.2015.11.008.

[43] Hossain, M.K., Karim, M.R., Chowdhury, M.R., Imam, M.A., Hosur, M., Jeelani, S., Farag, R. (2014). Comparative mechanical and thermal study of chemically treated and untreated single sugarcane fiber bundle. Industrial Crops and Products, vol. 58, p. 78-90, D0l:10.1016/j. indcrop.2014.04.002.

[44] Mohanty, A.K., Misra, M., Drzal, L.T. (2005). Natural Fibers, Biopolymers and Biocomposites. Taylor \& Francis Group, New York, DOI:10.1201/9780203508206. 